\title{
Essay
}

\section{Keeping It Real: Substantive Learning on a Short Calendar}

\section{Phoebe Lostroh}

\author{
Department of Biology, Colorado College, Colorado Springs, CO 80903
}

Submitted May 9, 2007; Revised June 14, 2007; Accepted June 23, 2007

Monitoring Editor: Elizabeth Vallen

\begin{abstract}
Many institutions offer courses that last less than a quarter and are a student's sole academic responsibility for that short term. There is an unfortunate and incorrect perception that such short classes cannot be used to teach substantively. At Colorado College, we teach all of our courses in $3.5 \mathrm{wk}$, including majors' courses in molecular cell biology and related fields. The article presents strategies for exploiting short terms as excellent venues for deep learning in the biological sciences.
\end{abstract}

Picture this: bright-eyed and bushy-tailed, a new assistant professor of biology at a selective liberal arts college. This new professor (me) is talking to an associate professor at a school sponsoring a workshop for new science faculty at similar colleges. She is dazzling me with their new facilities and obvious excellence in hands-on, minds-on teaching. When asked where I will be working, I respond, "Colorado College." She next asks me about what courses I will teach, and I explain that I will teach in the molecular end of the curriculum and that we teach all of our courses in "blocks" for $3.5 \mathrm{wk}$ at a time, with students enrolled in just that one class. "My goodness," she exclaims. "We teach a May Term for about a month every year, too, but we would never teach anything real then!" Almost immediately, she regrets the faux pas. I can only imagine the look on my freshly scrubbed face.

Her reaction has remained with me all this time. I now have 4 yr of experience teaching six biology courses a year in 3.5 wk each, so I can respond to her comment: Yes, of course you can teach something "real" in 3.5 wk. Naturally, everyone who teaches at Colorado College can report disastrous courses in which we struggled against the schedule's limitations instead of capitalizing on its strengths. But we can also report examples of using block-style teaching to powerful effect.

The possibilities of excellence in teaching and learning on this calendar should be of interest to many faculty. Although there aren't many schools that have adopted "The Colorado College Plan" of block teaching, quite a few institutions offer occasional courses that last less than a quarter and are a

DOI: $10.1187 /$ cbe.07-05-0024

Address correspondence to: C. Phoebe Lostroh (plostroh@colorado college.edu). student's sole academic responsibility for that short term. For instance, there might be a "J Term" for most of January, or a May Term just before graduation. I have had informal conversations with science faculty at institutions with J or May Terms, and the consensus is that there is absolutely no point in trying to teach anything "real" in a month. Most believe that month-long terms are best used for exposing nonscience majors to big ideas in science or for convincing nonmajors that science can be fun. A third popular option is to use block-style summer courses for teaching premedical undergraduates things that they don't actually want to know about, like Newtonian physics or organic chemistry. I think that this perception of short-term courses is wrong, and worse, that it undoubtedly leads faculty to waste a precious opportunity. Anyone can use "blocks," whenever they occur, to maximize student learning in rigorous, compelling courses, by teaching "something real."

It is useful to state the obvious, because the obvious was not apparent to me. If you are going to spend 18 weekdays in a row teaching something challenging that students ought to remember after the course has ended, do not simply take a 15-wk semester and set up the simple ratio that $1 \mathrm{wk}$ of semester $=1 \mathrm{~d}$ of a block, so therefore $18 \mathrm{~d}$ in the block $15 \mathrm{~d}$ of class $=3 \mathrm{~d}$ for exams. When I applied these deceptively simple equations to course design, I exhibited signs of serious semester chauvinism. Haunted by the question of keeping it real, I just couldn't envision any other solutions.

And so my first course (BY107: Introduction to Microbiology) was exactly like any eager neophyte's first semester course, but faster. I reasoned that I could use the 3 morning hours every day exactly as though we were all simply attending a full week of semester class in a single day. I figured that I should give the students a little break, so I set aside $\sim 30$ min every few days for quizzes and ended with a 
comprehensive final on the last day of class. I counted up the hours I spent in lab for introductory biology at the undergraduate liberal arts college I once attended and decided that it would be a huge disservice to my students if we didn't spend absolutely every weekday afternoon in the lab. Voila!: Introduction to Microbiology in a block.

How did it turn out? Well, in theory it is possible to deliver three 50-min lectures in the morning and then to spend $2 \mathrm{~h}$ in the lab every afternoon including Fridays. I did manage to make practice match theory. I could just barely get ready for class if I got to work at 5 A.M. and used lunch for lab prep. Students spent their evenings and weekends feverishly solving problems, writing papers, writing lab reports, making flashcards, and otherwise studying, while I, with equal fervor, spent every waking hour solving problems, grading lab reports and exams, and revising lectures. Certainly, no one accused me of failing in the "rigor" category. I'm pretty sure, however, that the students didn't really learn much microbiology, let alone any critical-thinking skills.

In retrospect, I think that I designed the course that way because I mistakenly tried to measure its merits with a semester-long yardstick. Since then, I have found that there seem to be two strategies adopted by happy, healthy professors with excellent reputations teaching science at Colorado College. Instead of bemoaning the calendar, they play to the strengths of short, focused blocks of time. They always go deep conceptually and usually they also take their students off-campus physically (or at least get out of the classroom). Examples of going deep in natural science courses include a seminar-style course that emphasizes critique of literature or a laboratory course in which small groups of students address an authentic research problem. I have seen colleagues build professional meeting attendance (by the whole class) into courses. Another colleague enjoys working with students on writing, so he uses a sophomore-level majors' course to focus on the process of discipline-specific writing, with a course limit that allows him and the students to spend time pondering and revising drafts.

Going deep for a field scientist involves both focused intellectual work and physically leaving the campus, as many of my biology, geology, and environmental science colleagues do. But you don't have to be a field scientist to take advantage of this strategy. I know faculty who ask environmental science majors to model heat flow in local low-income housing and then physically do simple, costeffective repairs to save energy and give back to our town. A biochemistry professor requires students in an advanced elective to use their newfound expertise in a peer education session, teaching the campus about HIV and AIDS. Still other colleagues assign the students to teach a critical concept to young children at the campus childcare center. The possibilities can be endlessly productive so long as they are intentional, integral components of a course.

I now teach introductory microbiology quite differently than I first did (see Supplemental Data 1). The course still has some features reminiscent of an intro-level survey course, such as lecturing in concert with laboratories, but I have tried to take advantage of the block plan instead of working against it. For example, I don't hold the students responsible for every detail in 15 chapters of a textbook. Instead, I have chosen to focus on bacteria, arguing that they are and always have been the most abundant life form and are therefore as representative of "life" as any organisms could possibly be. The other "content" goals include the interrelationship of structure and function, mechanisms and consequences of horizontal gene transfer, and basic ideas in molecular pathogenesis. The necessity of selecting a small number of interrelated topics was an excellent intellectual exercise for me: what is really important when introducing biology majors to the discipline of microbiology and the life of microbes?

We now spend a substantial period of morning classtime, once devoted to lecturing, on guided discussions, problemsolving, and other peer-to-peer teaching activities. I am "on stage" for a much smaller proportion of each day. We don't do a series of topically unconnected, technique-focused labs anymore, either. Instead, students learn fundamental microbiology skills such as aseptic technique, light microscopy, and dilution plating during the process of an authentic investigative project on biofilm formation by Vibrio fischeri. In the course, experimental design and analysis of laboratory-based evidence are as important as mastery of aseptic technique. Students must work together to digest the background reading, to select a testable, important hypothesis, and to proceed from there. Nor do I assign many lab reports and laboratory notebook collections. I do require formal discipline-specific writing about laboratory evidence, in the form of a primary research article. The first laboratoryassociated writing assignment is to write several sections of that "research article" (the Results and Methods), and the second (and last) laboratory-based writing assignment is to revise those sections according to feedback from peers and me and also to write the rest of the same lab report.

We still have regular objective examinations of the expected type, but now students take each midblock exam individually for $90 \mathrm{~min}$, instead of taking shorter quizzes, but then continuing with a new lecture topic afterward or taking an exam all morning before new lab work in the afternoon. After these first $90 \mathrm{~min}$, I randomly assign students to groups of four, and the groups retake the exact same exam for another hour. An individual's personal exam grade is the sum of $90 \%$ of their individual exam score and $10 \%$ of their group exam score. Doing well on the group exam provides sufficient motivation so that students with less than an A on their individual score are willing to participate in deciding what the answers should be on the group exam, whereas strong students who earned an A on their own are also eager to prevent the group from turning in wrong answers. The time devoted to the examination is therefore an additional learning experience for all the students rather than "lost time." As a bonus, I don't have to grade the exams in a hurry, because the whole class already knows most of the answers and can estimate their individual performance.

Finally, my course is embedded in the liberal arts at an institution committed to integrating traditional science learning with skills important across the curriculum. Students in Introduction to Microbiology therefore work on their information literacy, writing, and oral presentation skills through a researched project on "your favorite microbe" (YFM). YFM is a scaffolded assignment with intermediate graded stages, but it culminates in an oral seminar instead of a long written paper. Again, students must work 
together during classtime and throughout the project to identify an interesting microbe and to understand the secondary and primary sources that will ultimately inform their final seminar. The seminar series is enabled by the block plan, which provides several uninterrupted hours akin to those available at a professional meeting. I play on this atmosphere by spending a little of the course budget on coffee and bagels and requiring all students to ask at least two questions of their presenting peers for a small percentage of their YFM grade. All the seminars are due on the same day, and grading for the YFM component of the course is usually finished before students have turned in their final comprehensive exams (which have no group component).

A second example of a course, BY463 Bacteriology, also works well on the block plan and could readily be adapted for anyone's block-style course (see Supplemental Data 2). BY463 is a senior-level, seminar-style elective for biology and biochemistry majors; the topic is molecular microbiology (my research field). Every time I teach the course, I select eight topics that will be our collective focus. Approximately three times a week, I assign one professional review and two research publications addressing that topic. Reviews published in Nature Reviews Microbiology seem to work particularly well, and it is also important that the research publications be connected to one another in some way. For example, they could be written by the same authors or by authors in the same research lab. I've also used pairs of articles in which different laboratories have come to contradictory conclusions about the same research problem.

As a class, we talk about one of the eight sets of papers approximately every other day for about $3 \mathrm{~h}$. On in-between days, we have formal class only for about an hour. During that hour, students ask questions of fact related to the current all-class reading for part of the time. That process usually doesn't take too much time, though, and so we spend most of the hour discussing students' progress on their individual library-researched projects as a whole class. In these projects, they adopt a contemporary laboratory and imagine themselves as graduate students about to join that laboratory and undertake thesis work in it. Ultimately, they write a grant proposal-style paper defending a set of specific experiments intended to address a compelling open research question. Students spend much of their out-of-classroom time working on this researched project, and the result is high-quality work in which they usually surpass their own expectations. I have taught the course three times now, and there are two separate occasions in which Journal of Bacteriology articles included experiments closely paralleling BY463 student proposals even though the student proposals were written before publication of the research papers.

The substantial classtime students spend discussing their ideas with one another appears to enhance the final product, because they ask important questions of each other that I would never have posed. I believe that the block plan may also enable weaker students to write higher-quality grant proposals than they otherwise might, because the students have no other formal academic commitments to distract them from the task at hand. I have no empirical evidence to support this claim, other than conversations with such students in which they express how valuable it was to have had a long period of time devoted to the assignment. The block schedule also works particularly well for BY463 because we have abundant, flexible time in which I can pay close attention to the students' progress and guide the conversation appropriately. I never have to worry about a bell clamoring for class to end. If it seems that students really haven't understood a key technique, I can send them to a library of textbooks available in the classroom or to an Internet connection to answer some specific questions about that technique before the discussion continues. If, on the other hand, discussion of the assigned articles lasts for less time than anticipated, I can direct the students to work on a related activity. Last year, for example, the students developed an amazing seminar on metagenomics aimed at introductory microbiology students. I plan to use their superb presentation in an actual introductory class.

On our best discussion days, we move beyond the nittygritty to issues that transcend specific research articles. Because there are no other classes to rush off to, we have time to talk about those issues that advance student critical thinking, as described in Perry's work so long ago (1970) and by contemporary researchers such as Nelson (1989), and King and Kitchener (2004). For example, we always somehow talk about how research and publication are affected by personal and social factors. This last year, a student who had taken a lot of comparative literature led us to talk about how communicating in English as a foreign language might affect science. It shouldn't be a luxury to discuss social issues and science with our own majors in majors' courses, and with a little planning on the professor's part, such conversations are encouraged by block-style scheduling. Surely the world needs scientists who know how to confront philosophical, ethical, and social issues in science just as much as it needs philosophers, ethicists, and voters who know something about science.

Another reason that BY463 works well is that the block schedule enhances some of most desirable outcomes in any literature-focused biology elective. For example, students move from a primary stance of awe ("Those people have Ph.D.s; who am I to argue with their decisions?") to a stance of criticism ("I think that they can't draw that conclusion from the data available, and Science let them get away with it!"). Although this type of learning can happen in any class, no matter the schedule, a short, focused block enables students to make such a move so rapidly that even the least confident students can't help but notice their intellectual growth.

I developed the courses described here by talking to my colleagues, learning their block plan survival strategies, and then adapting them to my own personality and discipline. I have only recently encountered educational research, such as that of Nelson, King and Kitchener, and Perry, which provides a theoretical framework for understanding why the techniques seem to work (see References).

In 1989, Craig Nelson, a biologist, provoked college science professors with the argument that the trade-off between teaching content and critical thinking is an illusion, no more real than a unicorn's horn (Nelson, 1989). In a more recent article, he cites numerous studies that show the profound, positive ". . . effects of replacing a substantial portion of traditional coverage with required, guided student-student interaction" (Nelson, 1999). In fact, educational research has long demonstrated that structured peer interactions used intentionally during class time lead to substantive 
learning, defined not only as mastery of content but also as critical thinking in a discipline (reviewed in Nelson, 1989, 1996, 1999).

In workshops and seminars as well as in print, Nelson continues to argue that we scientists must teach critical thinking. He claims that to define learning in the sciences, of all disciplines, as the reliable accumulation of facts is to miss the point entirely (Nelson, 1989, 1999). It is to skewer oneself on a unicorn's horn: to be injured yet unaware of wounds that are unnecessary, self-inflicted, and mortal. As Nelson said during a January 2007 workshop at Colorado College, choosing long lists of lovingly selected content in our disciplines may feel good to us, the experts, but it inevitably curtails real, substantive learning. Real learning, instead, can only be defined as the development of a mature, reflective intellect, capable of making reasoned judgments based on inevitably incomplete information (Perry, 1970; King and Kitchener, 2004).

The time constraints of block plan teaching led me to discover peer-to-peer interactions as useful solutions to my classroom problems, without benefit of educational theory. The schedule provided a stressful environment in which my ideas about teaching simply had to evolve. It probably selected for peer-interactive pedagogies because they gave me a break from being on stage all day, every day. Thus, teaching on a short schedule forced me to hit upon classroom solutions that I am only now learning are part of a great tradition that has long advocated changing typical classroom activities in order to promote student learning. Perhaps you will find that the strategies that work in my classrooms might allow you to teach something real in your classes, too, however long those classes last.

\section{ACKNOWLEDGMENTS}

I am grateful to Bruce Voyles and Leslie Gregg-Jolly of Grinnell College for their constant encouragement and enduring mentorship. Thanks to the excellent teachers at Colorado College and to the staff at the Learning Commons of Colorado College for challenging and inspiring me. Amanda Udis-Kessler, Laura Hoopes, Mark Morgenstern, Shane Heschel, and an anonymous reviewer all made constructive comments on the manuscript.

\section{REFERENCES}

King, P., and Kitchener, K. (2004). Reflective judgment: theory and research on the development of epistemic assumptions through adulthood. Educ. Psychol. 39(1), 5-18.

Nelson, C. (1989). Skewered on the unicorn's horn: the illusion of tragic tradeoff between content and critical thinking in the teaching of science. In: Enhancing Critical Thinking in the Sciences, ed. L. Crow, Washington, DC: Society of College Science Teachers.

Nelson, C. E. (1996). Student diversity requires different approaches to college teaching, even in math and science. Am. Behav. Sci. 40, 165-175.

Nelson, C. E. (1999). On the persistence of unicorns: The tradeoff between content and critical thinking revisited. In: The Social Worlds of Higher Education: Handbook for Teaching in a New Century, ed. B. A. Pescosolido and R. Aminzade, Thousand Oaks, CA: Pine Forge Press.

Perry, W. (1970). Forms of Intellectual and Ethical Development in the College Years: A Scheme, New York: Holt, Rinehart \& Winston. 